\title{
Diversity of Macrobenthic Invertebrates in Relations to Some Selected Water Quality Parameters in Lagos Lagoon, Nigeria
}

\author{
Bassey, B. O., Nosazeogie, E. 0., Izge, M. A., Bello, B. 0., Abiodun, 0., Olapoju, 0., Ajani, G., Igbo, J. \\ K., Balogun, K. J. and Yakub, A. S. \\ Department of Biological Oceanography, Nigerian Institute for Oceanography and Marine Research (NIOMR), Victoria Island, \\ Lagos Nigeria. P.M.B. 12729
}

*Corresponding author: Bassey BO, Department of Biological Oceanography, Nigerian Institute for Oceanography and Marine Research (NIOMR), Victoria Island, Lagos Nigeria. P.M.B. 12729

\section{ARTICLE INFO}

Received: 蔧 August 21, 2020

Published: 慧 September 03, 2020

Citation: Bassey BO, Nosazeogie EO, Abdullahi IM, Bello B, Abiodun O,Olapoju O, Ajani G, Igbo J, Balogun JK, Yakub AS. Diversity of Macrobenthic Invertebrates in Relations to Some Selected Water Quality Parameters in Lagos Lagoon, Nigeria. Biomed J Sci \& Tech Res 30(1)-2020. BJSTR. MS.ID.004886.

Keywords: Diversity Indices; Benthic Macroinvertebrate; Water Quality; Lagoon

\section{ABSTRACT}

Species composition and diversity of benthic macroinvertebrate in relation to environmental variables are significant aspects of understanding the structure and function of coastal ecosystems. In this study, temporal and spatial variations in the distribution of macrobenthos in relation with environmental parameters were explored in nine stations along the Lagos Lagoon (May to December 2018). A total of 39 benthic macroinvertebrates belonging to 4 classes and 3 phyla were identified. Macrofauna were mainly composed of deposit feeders, dominated numerically by Molluscs. Diversity index analyses indicated that Simpson index varied from 0.71 in May to 0.90 in September, Shannon Weiner diversity values in the study area ranged from 1.43 to 2.46. Dominance index had the highest of 0.29 in May which reflects the complete dominance of few species and lowest with 0.10 in July. Margalef diversity index ranged between 1.60 to 3.99 and Evenness index also varied from 0.61 to 0.84 . PCA had $82.74 \%$ variability associated with principal components 1 and 2. The Physico-chemical parameters of the water were significantly correlated $(\mathrm{p}<0.05)$ with Equitability index. The diversity were significantly influenced by environmental factors, thus the study revealed that the Lagos Lagoon is under anthropogenic pressure from organic and inorganic forms of pollutions.

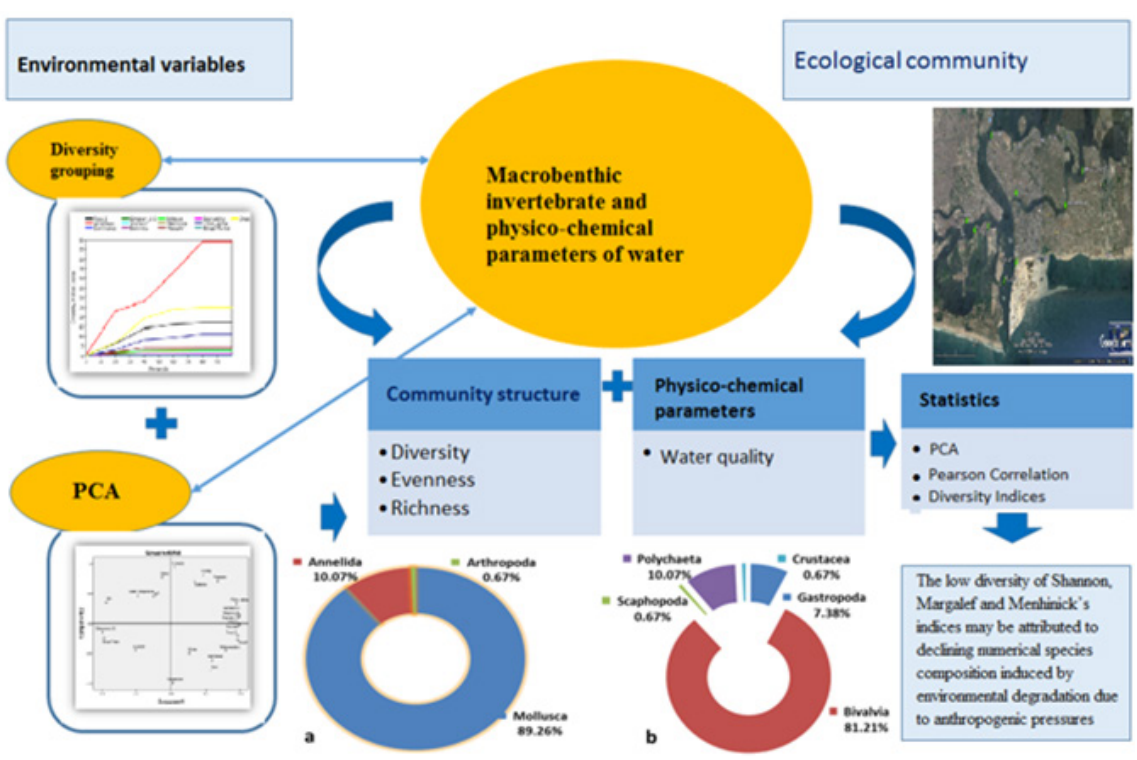




\section{Introduction}

In recent times, biological diversity has received increased attention in relation to environmental variables within coastal ecosystems. Bottom sediment habitats cover most of the coastal environments and as such support a diverse array of macrobenthic communities that play important roles in ecosystem processes such as recycling nutrients, detoxifying pollutants, dispersion and burial, and secondary production. Thus, the diversity and relative abundance of these organisms are commonly used in biomonitoring, to measure the ecological health status of aquatic ecosystems [1] Diversity within natural systems is important for their resilience to environmental change [2]. Therefore, species diversity, as an index measuring the number of species within a community, the proportional abundance of individual species, or both, is important

for determining the status of biological communities. Quantifying the diversity of biological systems, and understanding the patterns and dynamics of biodiversity in ecosystems is of utmost importance for monitoring, towards the management and conservation of ecosystems [3]. Diversity indices are important statistical measure used to characterize richness (the number of species) and evenness (how uniform abundant species are in a sample) of the species in the community [4] and is used as a tool for determining the health and pollution of an ecosystem [5]. Consequently, different indices of diversity were taken into account to highlight their importance with respect to benthic community. Understanding the structure of the benthic faunal communities in relation to the impacts of pollution is an important part of monitoring changes in coastal ecosystems in Nigeria.

Water quality and benthos characteristics have been investigated in coastal ecosystems around the world [6] and indicate that the health of benthic communities is related to water quality conditions infringing communities, such as Lagoons which serve important purposes such as navigational pathways, migratory and spawning ground for aquatic life forms, and other social benefits [7]. The Lagos Lagoon is a brackish water body in Lagos which spans approximately $150.56 \mathrm{~km} \mathrm{sq[8]} \mathrm{and} \mathrm{empties} \mathrm{into} \mathrm{the}$ Atlantic Ocean through the Commodore Channel to the west [9]. Environmental conditions like salinity, oxygen, temperature and nutrients influence the composition, distribution, and growth of biota [10]. Macrobenthic invertebrates of the Lagos lagoon have been extensively studied. Baseline information, as to the status of macrobenthic communities was done by [11]. Variation in the diversity and species composition of macrobenthic invertebrate communities in time and space has also been commonly explored $[12,13]$. Additionally, some benthos studies carried out in the Lagos in recent times have attempted to use macrobenthos as bioindicators of pollution [13-15]. Thus, this study aims to explore and understand spatial and temporal variation in macrobenthic diversity in relation to environmental variables in Lagos Lagoon.

\section{Materials and Methods}

\section{Study Area}

Lagos lagoon is a major part of the barrier Lagoon complex extends eastwards for about $200 \mathrm{~km}$ from the Nigerian-Benin Republic border to the western limit of the transgressive mud coast of the Nigerian coastal zone. The Lagoon is located between latitude $6026^{\prime} \mathrm{N}$ and 6o 38' $\mathrm{N}$ longitude 3o 23' E and 3o 43' E. It covers an area of about $208 \mathrm{~km} 2$ (FAO, 1969). It is generally between 0.5 $2 \mathrm{~m}$ deep in most parts with a maximum of about $5 \mathrm{~m}$ in the main lagoon and $25 \mathrm{~m}$ in some dredged parts of the Lagos Harbour. The tidal range is only about $0.3 \mathrm{~m}-1.3 \mathrm{~m}$. The interconnecting creeks are also very shallow and are sites of active silting and deposition of mud. The lagoon sediments range between mud, sandy mud, muddy sand, and sand[11]. Nine sampling stations were selected based on proximity to the sources of different forms of contaminants generated from anthropogenic activities discharged into the Lagoon. The coordinates of each sampling stations were determined with the aid of the Global Positioning System (GPS) (Figure $1 \&$ Table 1).

Table 1: Stations and co-ordinates.

\begin{tabular}{|c|c|c|}
\hline Sampling Stations & \multicolumn{2}{|c|}{ Co-ordinates } \\
\hline NIOMR Jetty & N06을 $25.148^{\prime}$ & $\mathrm{E}^{\prime} 03^{\circ} 24.455^{\prime}$ \\
\hline Atlas Cove & N06을 $24.789^{\prime}$ & ${\mathrm{E} 003^{\circ} 23.849^{\prime}}^{\prime}$ \\
\hline Sabon-Kwoji & 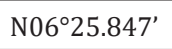 & ${\mathrm{E} 003^{\circ} 22.975^{\prime}}^{\prime}$ \\
\hline Folawiyo & N06일. & $\mathrm{E} 003^{\circ} 22.272^{\prime}$ \\
\hline Crown Flour Mill & 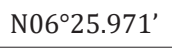 & $\mathrm{E} 003^{\circ} 21.826^{\prime}$ \\
\hline Ebute-Ero & N06 ${ }^{\circ} 27.758^{\prime}$ & $\mathrm{E}^{\prime} 03^{\circ} 23.018^{\prime}$ \\
\hline Civil Service Club & N06을 & $\mathrm{E}^{2} 03^{\circ} 24.412^{\prime}$ \\
\hline Lekki Shoprite Area & N06을.292' & $\mathrm{E} 003^{\circ} 27.041^{\prime}$ \\
\hline Lekki Sewage Disposal & N06일 $27.007^{\prime}$ & E003 $27.979^{\prime}$ \\
\hline
\end{tabular}

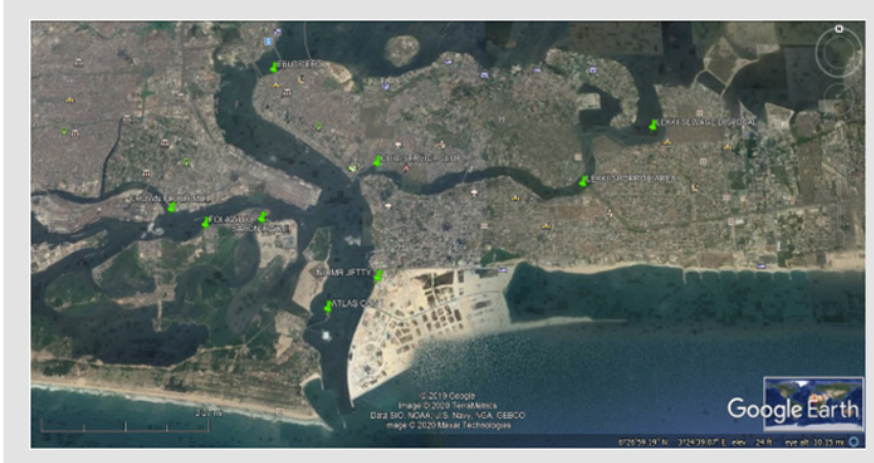

Figure 1: Map of sampling stations along the Lagos Lagoon and Harbour.

\section{Collection of Samples}

Surface water and sediment samples were collected on a motorized boat, stored in a labeled container and transported to the laboratory where it was stored in the refrigerator at the 
temperature of -5oC. Surface water samples were collected with 1 Litre container, while a $250 \mathrm{ml}$ Amber bottle was used to collect water samples for dissolved oxygen and biological oxygen demand estimation using iodometric Winkler's method. Sediment samples were collected concurrently using a Van-veen grab of $1 \mathrm{~m} 2$. The sample were collected from May to December 2018.

\section{Benthic Macrofauna Analyses}

At each study station, 2-3 composite grab hauls were sieved in-situ using a $0.5 \mathrm{~mm}$ mesh-size sieve [14], fixed in $10 \%$ formalin and labeled for macrobenthic fauna analysis and placed in a plastic sealed container and transported to the laboratory for proper sorting, identification, and counting. Relevant texts (Olaniyan, 1968; Yankson and Kendall, 2001; Zar, 1984) were used for identification.

\section{Measurement of Physico-Chemical Characteristics}

Mercury in-glass thermometer was employed in determining temperature. Dissolved oxygen, Biological oxygen demand, and turbidity were determined using a Smart spectrophotometer by LaMotte. Salinity was measured using a refractometer; while alkalinity was done by titration method. Total Dissolved Solids, $\mathrm{pH}$ and conductivity were measured with a multi-meter probe $\left(\right.$ Oakton $\left.^{\mathrm{TM}}\right)$.

\section{Statistical Analyses}

Diversity indices such as Margalef's index for species richness, Shannon-Wiener and Simpson's indices for species diversity, and the Equitability index for evenness of the benthic macroinvertebrates were estimated using PAST 3.18, while variations in physicochemical parameters between stations and sampling periods were also explored using analysis of variance (ANOVA). All the other analyses were done using the $\mathrm{R}$ statistical software (R Development Core Team 2008): the response variables were subjected to the ShapiroWilk's normality test in order to determine the appropriate statistical tests to use $[15,16]$. Due to the non-normal distribution of the response variables (diversity indices), as determined by the Shapiro-Wilk's normality test, Generalized Linear Models (hereafter, GLMs) were fitted using the glm function (Thomas et al. 2015). These GLMs were used to explore the spatial and temporal variation in benthos diversity. We chose to use only two diversity indices (Shannon-Wiener diversity and species richness) as all the diversity indices are typically correlated. The GLMs were also used to investigate relationships between physicochemical parameters and benthos diversity.

\section{Results and Discussion}

The mean variation of the Physico-chemical characteristics of the water samples in the area across the period of sampling is shown in Table 2. The analysis of variance (ANOVA) showed significant differences $(\mathrm{p}<0.05)$ in $\mathrm{pH}$, TDS, alkalinity, salinity, water temperature, air temperature, nitrate, sulphate, and turbidity across the sampling period. Most of the physicochemical parameters varied temporally, and this may be attributed to temporal patterns of rainfall and tidal fluctuations. But the parameters did not vary spatially, Physical conditions in the Lagos lagoon have previously been described as relatively constant (Hill and Webb 1958). This suggests that the Lagos Lagoon is a homogenous environment for macrobenthos communities.

Table 2: Mean variation of Physico-chemical parameters in the Lagos Lagoon.

\begin{tabular}{|c|c|c|c|c|c|c|c|c|c|c|c|c|}
\hline & & pH & TDS & Conductivity & DO & Alkalinity & Salinity & $\begin{array}{c}\text { Water } \\
\text { Temperature }\end{array}$ & $\begin{array}{c}\text { Air } \\
\text { Temperature }\end{array}$ & Nitrate & Sulphate & Turbidity \\
\hline \multirow[t]{3}{*}{ May } & $\begin{array}{l}\text { Mean } \\
\pm \text { S.E }\end{array}$ & $\begin{array}{l}7.47 \pm \\
0.04 \mathrm{~b}\end{array}$ & $\begin{array}{c}2.23 \pm \\
0.16 \mathrm{a}\end{array}$ & $5.00 \pm 0.84$ & $6.12 \pm 0.62 a$ & $\begin{array}{c}77.11 \pm \\
3.51 \mathrm{~b}\end{array}$ & $\begin{array}{c}18.8 \pm \\
1.60\end{array}$ & $28.50 \pm 0.20 \mathrm{~b}$ & $23.89 \pm 0.42 \mathrm{a}$ & $\begin{array}{c}0.67 \pm \\
0.08 \mathrm{a}\end{array}$ & $\begin{array}{c}305.56 \pm \\
55.30 \mathrm{a}\end{array}$ & $\begin{array}{l}8.56 \pm \\
1.55 \mathrm{a}\end{array}$ \\
\hline & Min & 7.3 & 1.55 & $1.75 \mathrm{a}$ & 2.7 & 50 & 13 & 27.5 & 23 & 0.3 & 90 & 4 \\
\hline & Max & 7.6 & 2.8 & 8.26 & 8 & 86 & 27 & 29 & 27 & 0.98 & 540 & 20 \\
\hline \multirow[t]{3}{*}{ July } & $\begin{array}{l}\text { Mean } \\
\pm \text { S.E }\end{array}$ & $\begin{array}{l}7.73 \pm \\
0.11 \mathrm{~b}\end{array}$ & $\begin{array}{l}4.36 \pm \\
0.84 \mathrm{~b}\end{array}$ & $5.89 \pm 1.34 \mathrm{a}$ & $5.01 \pm 1.04 a$ & $\begin{array}{c}48.44 \pm \\
4.73 a\end{array}$ & $\begin{array}{c}16.93 \pm \\
1.87\end{array}$ & $28.44 \pm 0.23 b$ & $26.50 \pm 0.17 b$ & $\begin{array}{c}0.19 \pm \\
0.04 \mathrm{a}\end{array}$ & $\begin{array}{c}141.11 \pm \\
43.35 a\end{array}$ & $\begin{array}{c}22.22 \pm \\
5.14 \mathrm{~b}\end{array}$ \\
\hline & Min & 7.3 & 0.91 & 0.13 & 2.1 & 32 & 2 & 28 & 26 & 0.01 & 75 & 8 \\
\hline & Max & 8.21 & 7.44 & 10.56 & 10.8 & 72 & 29 & 30 & 27 & 0.41 & 350 & 45 \\
\hline \multirow[t]{2}{*}{ Sept } & $\begin{array}{l}\text { Mean } \\
\pm \text { S.E }\end{array}$ & $\begin{array}{l}7.58 \pm \\
0.09 \mathrm{~b}\end{array}$ & $\begin{array}{c}2.22 \pm \\
0.52 \mathrm{a}\end{array}$ & $3.18 \pm 0.74 \mathrm{a}$ & $5.30 \pm 0.86 a$ & $\begin{array}{c}49.33 \pm \\
2.92 \mathrm{a}\end{array}$ & $\begin{array}{c}7.33 \pm \\
1.61\end{array}$ & $28.28 \pm 0.09 b$ & $25.83 \pm 0.08 b$ & $\begin{array}{c}0.38 \pm \\
0.02 \mathrm{a}\end{array}$ & $\begin{array}{c}714.29 \pm \\
54.40 \mathrm{a}\end{array}$ & $\begin{array}{r}39.0 \pm \\
6.17 \mathrm{c}\end{array}$ \\
\hline & Min & 7.21 & 0.35 & 0.49 & 2.2 & 36 & 2 & 28 & 25.5 & 0.25 & 100 & 18 \\
\hline \multirow[t]{3}{*}{ Dec } & $\begin{array}{l}\text { Mean } \\
\pm \text { S.E }\end{array}$ & $\begin{array}{c}6.65 \pm \\
0.13 \mathrm{a}\end{array}$ & $\begin{array}{l}4.17 \pm \\
0.30 \mathrm{~b}\end{array}$ & $5.93 \pm 0.42 a$ & $4.67 \pm 0.78 \mathrm{a}$ & $\begin{array}{c}76.75 \pm \\
3.21 \mathrm{~b}\end{array}$ & $\begin{array}{c}24.67 \pm \\
3.07\end{array}$ & $26.22 \pm 0.15 a$ & $29.22 \pm 0.15 c$ & $\begin{array}{c}2.60 \pm \\
0.69 \mathrm{~b}\end{array}$ & $\begin{array}{c}497.78 \pm \\
43.59 \mathrm{~b}\end{array}$ & $\begin{array}{c}8.78 \pm \\
1.43 a\end{array}$ \\
\hline & Min & 5.93 & 3.25 & 4.64 & 2.8 & 60 & 2 & 26 & 29 & 0.04 & 95 & 3 \\
\hline & $\operatorname{Max}$ & 8.21 & 5.76 & 8.15 & 7.7 & 90 & 29 & 27 & 30 & 5.46 & 1224 & 16 \\
\hline $\begin{array}{l}\text { WHO// } \\
\text { FMEnv. }\end{array}$ & & $6-8$ & & 70 & $>6$ & 100 & & & & 20 & & \\
\hline
\end{tabular}


The lowest mean DO value of $4.67 \pm 0.78 \mathrm{a} \mathrm{mg} / \mathrm{l}$ was observed in December which fell below the permissible limit of $5.0 \mathrm{mg} / \mathrm{l}$ for WHO/FMEnv and this could be due to discharge of industrial effluents containing high concentration of organic matter and nutrient. Dissolved Oxygen is considered one of the most important parameters for assessing water quality as it regulates the distribution of flora and fauna [17]. The DO values of this study was similar to those reported for many other polluted Nigerian waters including 6.9 - $8.8 \mathrm{mg} / \mathrm{l}$ for Lagos lagoon [18], 4.00-7.50 mg/l for Luubara creek in Niger Delta $[19,20]$ and 1.20 - $9.40 \mathrm{mg} / \mathrm{l}$ reported by Victor and [21] and [22] for some polluted water bodies in Nigeria. The $\mathrm{pH}$ values of water from nine sampling stations were found to fluctuate from 5.93 to 8.21 with the least observed in December which was slightly acidic. The nitrate concentration of the surface water is normally low, but can reach high levels from agricultural runoff, or from contamination by human or animal wastes [23]. Nitrates ranged between $0.19 \pm 0.04$ a (July) and 2.60 $\pm 0.69 \mathrm{~b}$ (December) values were below the maximum permissible limit of $20 \mathrm{mg} / \mathrm{l}$. The low concentration of nitrate might be due to absence of eutrophication. However, this finding corroborates the findings of Ehiagbonare and Ogunrinde (2010) who reported nitrate value of between $2.21 \mathrm{mg} / \mathrm{l}$ and $4.91 \mathrm{mg} / \mathrm{l}$.

\section{Species Composition, Abundance and Diversity of Benthic Macroinvertebrates in Lagos Lagoon}

A total of 39 benthic macroinvertebrates belonging to 4 classes and 3 phyla were collected from nine (9) stations in the Lagos Lagoon (Table 3) and percentage composition in Figure 2. The phylum Mollusca dominated with $89.26 \%$ and the least was Arthropoda with $0.67 \%$. This dominance of molluscs may be typical of brackish water benthos [24]. From the study, the low number of benthic macroinvertebrates encountered could be due to some ecological imbalance arising from alterations of some important factors (including water quality, immediate substrates for occupation and food availability) governing the abundance and distribution of the benthic communities (Andem et al., 2012). Wide fluctuations were observed in the abundance of taxa across the station and sampling period. The diversity indices distribution patterns in relation to the sampling period are presented in Table 4 \& Figure 3.

Table 3: Benthic Macroinvertebrates composition across the sampling period in Lagos Lagoon.

\begin{tabular}{|c|c|c|c|c|}
\hline Taxa & May & July & September & December \\
\hline \multicolumn{5}{|l|}{ Phylum } \\
\hline \multicolumn{5}{|l|}{ Mollusca } \\
\hline \multicolumn{5}{|l|}{ Gastropoda } \\
\hline Fissurellasp & & 1 & & \\
\hline NaticaflammulataRequien, 1848 & & & & 2 \\
\hline Naticasp Scopoli, 1777 & & & & 1 \\
\hline Pachymelaniaaurita & 2 & & & \\
\hline Thais forbesii Dunker, 1853 & & & & 1 \\
\hline Turritella cingulifera & & & 1 & 2 \\
\hline Turritella torulosa Kiener, 1843 & & & 1 & \\
\hline Tympanotonusfuscatusvar radula & & & & 2 \\
\hline $\begin{array}{c}\text { Tympanotonusfuscatus } \\
\text { Linnaeus, } 1758\end{array}$ & & 1 & 1 & \\
\hline \multicolumn{5}{|l|}{ Bivalvia } \\
\hline Aloidissp & & & 2 & \\
\hline Aloidis trigons & & 2 & & \\
\hline Arca senilis Linnaeus, 1758 & & 3 & & \\
\hline Arca sp & & & 1 & \\
\hline Arca subglobosa Kobelt, 1889 & & 1 & & \\
\hline CardiumcostatumLinnaeus, 1758 & & 3 & & 1 \\
\hline Cardiumsp & & 1 & & \\
\hline Donaxacutangulus Deshayesin Reeve, 1854 & & 2 & & \\
\hline DonaxburnupiG. B. Sowerby III, 1894 & & & 5 & \\
\hline Donaxrugosus Linnaeus, 1758 & 1 & & & \\
\hline Dreissenaafricana Van Beneden, 1835 & & 13 & & 10 \\
\hline Macomacumana & 8 & 4 & 1 & 1 \\
\hline Mactra glabrata Gmelin, 1791 & & & 3 & \\
\hline Mytilus edulis & & & 4 & \\
\hline
\end{tabular}




\begin{tabular}{|c|c|c|c|c|}
\hline Mytilus perna (Linnaeus, 1758) & & 12 & & 1 \\
\hline Ostrea tulipa Lamarck, 1819 & & & 2 & 7 \\
\hline Ostrea sp Linnaeus, 1758 & & 10 & & \\
\hline Pecten sp & & & & 1 \\
\hline Pinna rudis Linnaeus, 1758 & & 1 & & 5 \\
\hline Pitariatumens & & & & 1 \\
\hline Solen guinensis Hanley, 1842 & 2 & & & \\
\hline Tellinasp & & & 2 & \\
\hline Tellinanymphalis & & 1 & & \\
\hline Tellinatrilatera Gmelin, 1791 & & & 3 & \\
\hline Tivelatripla(Linnaeus, 1771) & & & 1 & 6 \\
\hline \multicolumn{5}{|c|}{ Scaphopoda } \\
\hline Dentalium $s p$ & & & & 1 \\
\hline \multicolumn{5}{|l|}{ Phylum: } \\
\hline \multicolumn{5}{|l|}{ Annelida } \\
\hline \multicolumn{5}{|l|}{ Polychaeta } \\
\hline Capitella capitata & 9 & 1 & & \\
\hline Orbiniida & & 1 & & \\
\hline Nereis sp Linnaeus, 1758 & & 2 & 1 & 1 \\
\hline \multicolumn{5}{|l|}{ Arthropoda } \\
\hline \multicolumn{5}{|l|}{ Crustacea } \\
\hline Penaeus notialis & 1 & & & \\
\hline
\end{tabular}
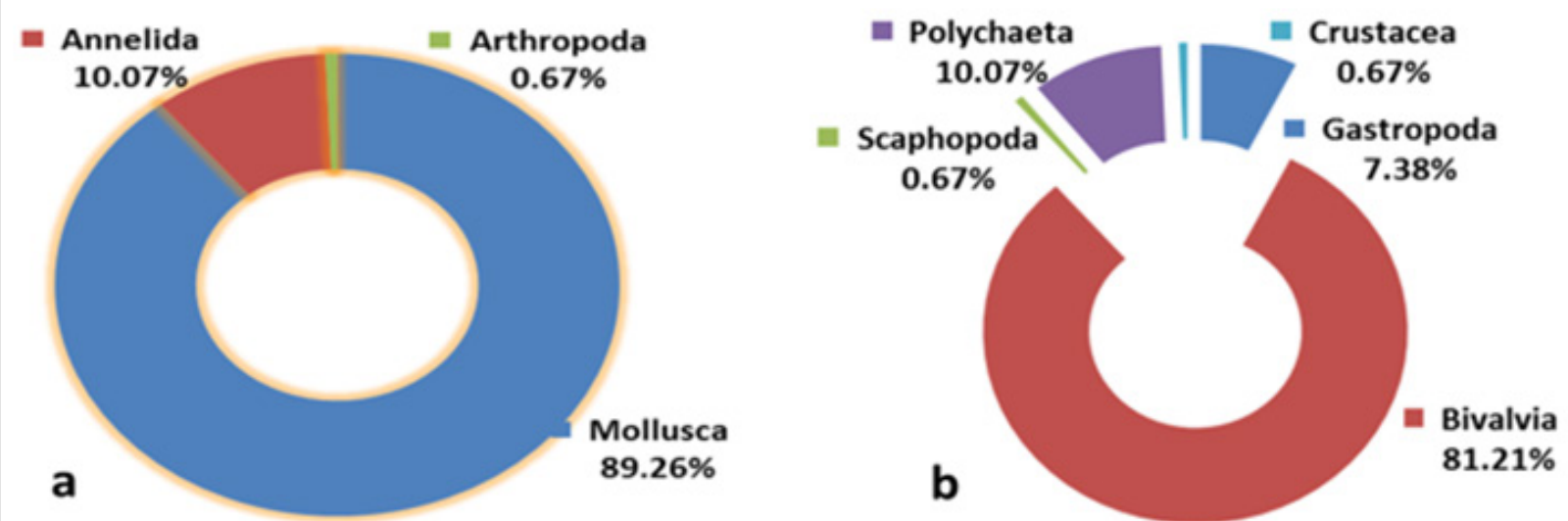

Figure 2: Percentage composition of (a) Phylum and (b) Classes of macrobenthic invertebrate Lagos Lagoon. 

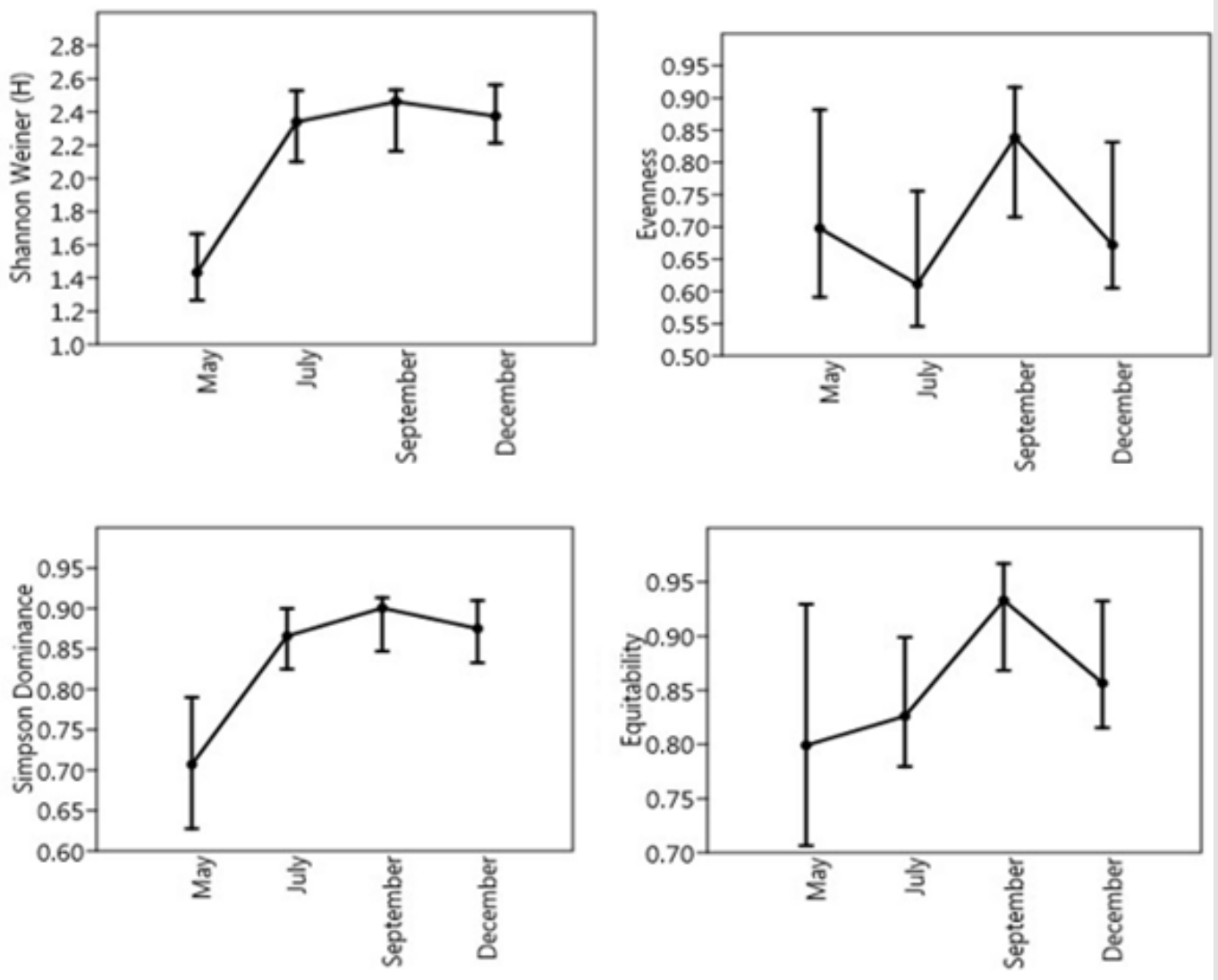

Figure 3: Diversity Indices of benthic macroinvertebrate across the sampling period.

Table 4: Diversity Indices of Benthic Macroinvertebrates across the sampling period in Lagos Lagoon.

\begin{tabular}{|c|c|c|c|c|}
\hline Diversity indices & May & July & September & December \\
\hline Taxa_S & 6 & 17 & 14 & 16 \\
\hline Individuals & 23 & 59 & 0.1 & 0.12 \\
\hline Dominance_D & 0.29 & 0.13 & 0.9 & 0.88 \\
\hline Simpson_1-D & 0.71 & 0.87 & 2.46 & 2.38 \\
\hline Shannon_H & 1.43 & 2.34 & 0.84 & 0.67 \\
\hline Evenness_e^H/S & 0.7 & 0.61 & 1.94 & 2.96 \\
\hline Brillouin & 1.17 & 2 & 3.9 & 2.44 \\
\hline Menhinick & 1.25 & 2.21 & 0.93 & 3.99 \\
\hline Margalef & 1.6 & 3.92 & 11.14 & 0.86 \\
\hline Equitability_J & 0.8 & 0.83 & 0.18 & 9.23 \\
\hline Fisher_alpha & 2.64 & 8 & 19.25 & 25 \\
\hline Berger-Parker & 0.39 & 0.22 & & \\
\hline Chao-1 & 6.33 & 24 & & \\
\hline
\end{tabular}

While assessing the Macrobenthic community of the Lagos Lagoon, Dominance index had highest of 0.29 in May which reflects complete dominance of few species and lowest with 0.10 in July. Generally, Simpson index ranges from 0 to 1 . Mature and stable communities have high diversity value ( 0.6 to 0.9 ), while the communities under stress conditions, exhibiting low diversity, usually show close to zero value [25]. Simpson diversity index is always higher where the community is dominated by less number of species and when the dominance is shared by large number of species [4]. In the present study, Simpson index varied from 0.71 in May to 0.90 in September and as such the Lagoon system had moderate anthropogenic pressures. 
In biological communities, Shannon-Wiener diversity index varies from 0 to 5 . According to this index, values less than 1 characterize heavily polluted conditions, and values in the range of 1 to 2 are characteristics of the moderate polluted conditions while the value above 3 signifies stable environmental conditions [4]. Shannon Weiner diversity values in the study area ranged from 1.43 to 2.46. Thus, these values suggest that the Lagos Lagoon is moderately polluted and the macro benthic community is under stress due to natural and/or anthropogenic factors. Margalef index has no limit value and it shows a variation depending upon the number of species. Thus, it is used for comparison of the sites [4] and takes only one component of diversity (species richness) into consideration reflecting sensitivity to sample size. In the present study, the values of Margalef diversity index were between 1.60 to 3.99. Evenness index also varied from 0.61 to 0.84 in Lagos
Lagoon. The low diversity of Shannon, Margalef and Menhinick's indices in this study may be attributed to declining numerical species composition induced by environmental degradation due to anthropogenic pressures, besides other biotic factors [26].

\section{Principal Component Analysis}

In the PCA analyses, variables associated with principal components 1 and 2 accounted for $82.74 \%$ variability among the samples (Figure 4). The Eigen value exceeded 1 for $\mathrm{pH}$, TDS, and conductivity. The PC 1 showed that sulphate and turbidity had significant impact on the species evenness, Shannon-Weiner, Simpson dominance, and Equitability indices, while PC 2 showed that Nitrate and TDS had a significant impact on the total number of individuals, numerical species taxa, and Margalef indices of the benthic macroinvertebrate from the Lagos Lagoon.

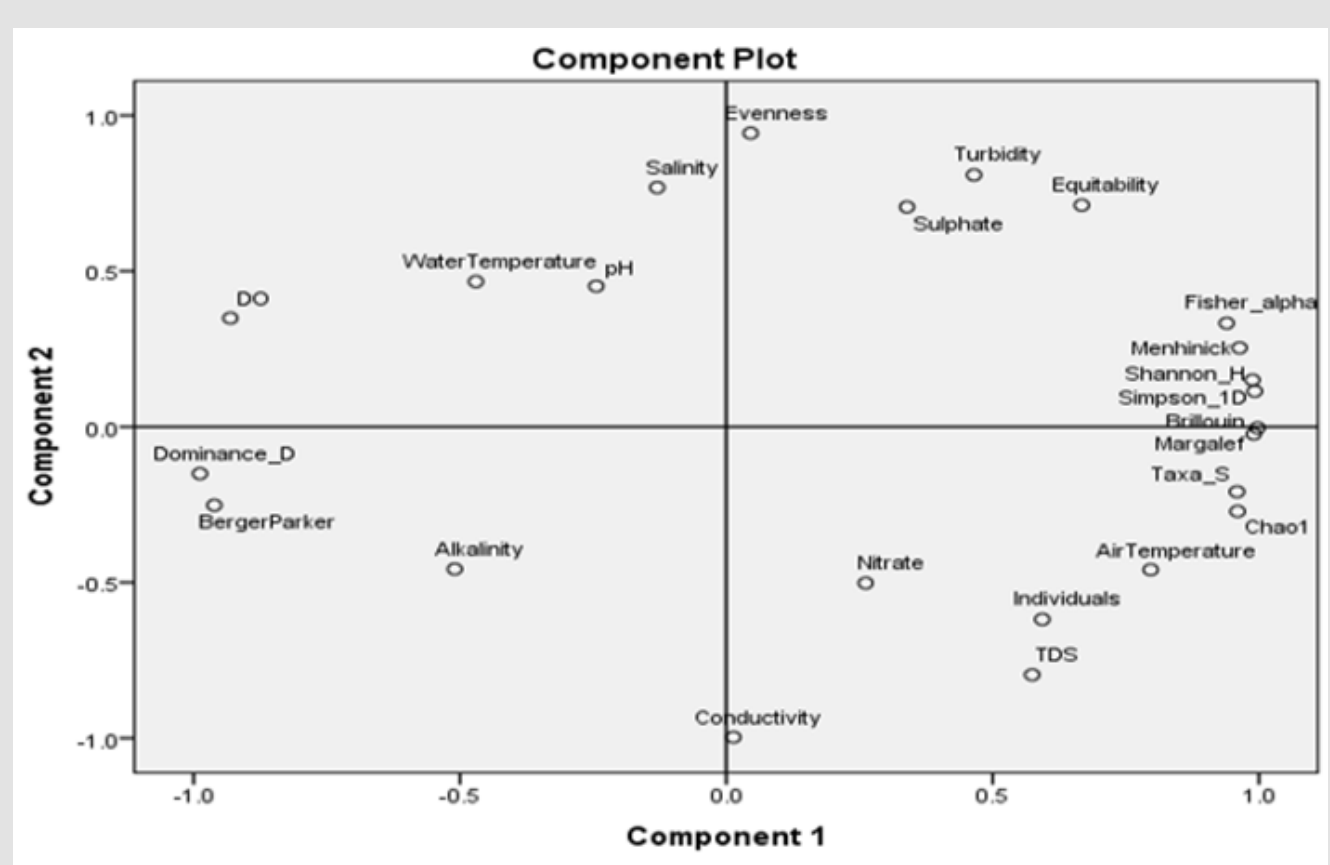

Figure 4: Principal component analysis of physico-chemical parameters and diversity indices of benthic macroinvertebrate of the Lagos Lagoon.

\section{Relationship Between Benthic Fauna and Environmental Factors}

The Pearson correlation coefficients ( $r$ ) values between the benthic macro-invertebrates and with physicochemical parameters are presented in Tables 5. All Physico-chemical parameters showed significant correlations $(\mathrm{p}<0.05)$ with Equitability index, while pH correlated Fisher Alpha index $\left(r=0.963^{*}, \mathrm{p}<0.05\right)$ and Berger Parker index $\left(r=-0.965^{*}, \mathrm{p}<0.05\right)$.

\section{Multivariate Statistical Analysis}

The Cluster analysis revealed three distinct groups of the diversity indices of benthic macroinvertebrate which reflect differences in habitat types and influences to environmental factors within Lagos Lagoon (Figure 5a). The first group consists of (1) Fisher alpha and taxa numerical species; second group has (2a) Simpson's dominance, Equitability, and Evenness, (2b) Shannon Weiner, Margalef and Menhinick's indices; while the third group (3) has Dominance and Berger Parker indices. The percentage diversity values were largely dominated by Bivalves with numerical abundance, numerical species and Dominance closely related, as well as Margalef and Menhinick's indices (Figure 5b). The Generalized Linear Models (GLMs) showed that neither species richness nor species diversity varied significantly between space i.e. stations (species richness: F8,36= 1.3565, p>0.1; diversity: F8,36=1.2827, $>0$. 1) and time i.e. date (species richness: $F 3,36=1.2907, p>0$. 1; diversity: $F 3,36=$ $0.8163, \mathrm{p}>0.1$ ). Thus, we present (statistical) evidence for the absence of both spatial and temporal variation in macrobenthic diversity within the Lagos Lagoon using regression analysis (GLMs). 
Table 5: Pearson Correlation Coefficient of Physico-chemical parameters and diversity indices of benthic macroinvertebrate of the Lagos Lagoon.

\begin{tabular}{|c|c|c|c|c|c|c|c|c|c|c|c|c|c|c|c|c|c|c|c|c|c|c|c|c|}
\hline & $\frac{T}{2}$ & $\stackrel{\sim}{\circ}$ & 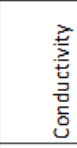 & 8 & 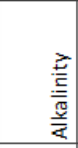 & $\begin{array}{l}\frac{\vec{t}}{\Xi} \\
\frac{\vec{E}}{\pi}\end{array}$ & 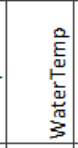 & $\begin{array}{l}\frac{0}{E} \\
\frac{5}{2} \\
\frac{5}{c}\end{array}$ & 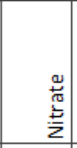 & 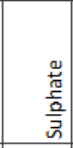 & 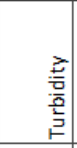 & 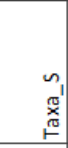 & $\begin{array}{l}\frac{n}{\pi} \\
\frac{n}{2} \\
\frac{\partial}{2} \\
\underline{\underline{z}}\end{array}$ & 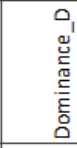 & 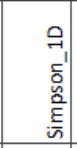 & 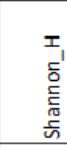 & 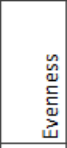 & 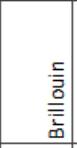 & 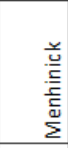 & $\begin{array}{l}\frac{\omega}{\omega} \\
\frac{\omega}{\pi} \\
\frac{0}{\pi} \\
\Sigma \\
\Sigma\end{array}$ & 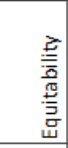 & 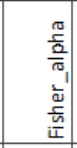 & 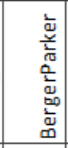 & 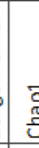 \\
\hline $\mathrm{pH}$ & 1 & & & & & & & & & & & & & & & & & & & & & & & \\
\hline TDS & $.969^{*}$ & 1 & & & & & & & & & & & & & & & & & & & & & & \\
\hline Conductivity & $.983^{*}$ & $.998^{* *}$ & 1 & & & & & & & & & & & & & & & & & & & & & \\
\hline DO & $.986^{*}$ & $.997^{* *}$ & $1.000^{* *}$ & 1 & & & & & & & & & & & & & & & & & & & & \\
\hline Alkalinity & $.994^{* *}$ & $.991^{* *}$ & $.998^{* *}$ & $.999 * *$ & 1 & & & & & & & & & & & & & & & & & & & \\
\hline Salinity & $.965^{*}$ & $1.000^{* *}$ & $.996^{* *}$ & $.995^{* *}$ & $.988^{*}$ & 1 & & & & & & & & & & & & & & & & & & \\
\hline WaterTemp & $.983^{*}$ & $.998^{* *}$ & $1.000^{* *}$ & $1.000^{* *}$ & $.998^{* *}$ & $.997^{* *}$ & 1 & & & & & & & & & & & & & & & & & \\
\hline AirTemp & $.986^{*}$ & $.997^{* *}$ & $1.000^{* *}$ & $1.000^{* *}$ & $.999^{* *}$ & $.995^{* *}$ & $1.000^{* *}$ & 1 & & & & & & & & & & & & & & & & \\
\hline Nitrate & 0.879 & $.969^{*}$ & $.951^{*}$ & 0.946 & 0.927 & $.974^{*}$ & $.951^{*}$ & 0.946 & 1 & & & & & & & & & & & & & & & \\
\hline Sulphate & 0.823 & \begin{tabular}{|l|}
0.937 \\
\end{tabular} & 0.912 & 0.907 & 0.882 & 0.944 & 0.913 & 0.906 & $.994^{* *}$ & 1 & & & & & & & & & & & & & & \\
\hline Turbidity & 0.923 & $.989^{*}$ & $.977^{*}$ & $.974^{*}$ & $.961^{*}$ & $.992^{* * *}$ & $.978^{*}$ & $.974^{*}$ & $.995^{* *}$ & $.978^{*}$ & 1 & & & & & & & & & & & & & \\
\hline Taxa_S & 0.743 & 0.582 & 0.629 & 0.638 & 0.674 & 0.568 & 0.627 & 0.639 & 0.385 & 0.293 & 0.469 & 1 & & & & & & & & & & & & \\
\hline Individuals & 0.264 & 0.023 & 0.089 & 0.102 & 0.155 & 0.005 & 0.086 & 0.103 & \begin{tabular}{|l|}
-0.219 \\
\end{tabular} & -0.319 & -0.12 & 0.797 & 1 & & & & & & & & & & & \\
\hline Dominance_d & -0.928 & -0.845 & -0.872 & \begin{tabular}{|l|}
-0.877 \\
\end{tabular} & -0.896 & -0.836 & $\mid-0.871$ & -0.877 & -0.71 & -0.638 & -0.771 & -0.923 & -0.511 & 1 & & & & & & & & & & \\
\hline Simpson_1D & 0.928 & 0.845 & 0.872 & 0.877 & 0.896 & 0.836 & 0.871 & 0.877 & 0.71 & 0.638 & 0.771 & 0.923 & 0.511 & $-1.000^{* *}$ & 1 & & & & & & & & & \\
\hline Shannon_H & 0.915 & \begin{tabular}{|l|}
0.824 \\
\end{tabular} & 0.853 & 0.859 & 0.879 & 0.815 & 0.852 & 0.859 & 0.681 & 0.607 & 0.745 & 0.937 & 0.544 & $-.999 * *$ & $.999^{* *}$ & 1 & & & & & & & & \\
\hline Evenness & 0.469 & 0.664 & 0.615 & 0.605 & 0.563 & 0.677 & 0.617 & 0.604 & 0.818 & 0.869 & 0.761 & -0.216 & -0.726 & -0.176 & \begin{tabular}{|l|}
0.176 \\
\end{tabular} & 0.137 & 1 & & & & & & & \\
\hline Brillouin & 0.856 & 0.728 & 0.767 & 0.775 & 0.803 & 0.717 & 0.765 & 0.775 & 0.557 & 0.472 & 0.632 & $.981^{*}$ & 0.673 & $-.980^{*}$ & $.980^{*}$ & $.987^{*}$ & -0.022 & 1 & & & & & & \\
\hline Menhinick & 0.944 & 0.899 & 0.916 & 0.919 & 0.93 & 0.893 & 0.915 & 0.919 & \begin{tabular}{|l|}
0.798 \\
\end{tabular} & 0.74 & 0.846 & 0.856 & 0.373 & $-.988^{*}$ & $.988^{*}$ & $.981^{*}$ & 0.311 & 0.937 & 1 & & & & & \\
\hline Margalef & 0.863 & 0.75 & 0.785 & 0.792 & 0.817 & \begin{tabular}{|l|l|}
0.739 \\
\end{tabular} & 0.783 & 0.792 & 0.59 & 0.51 & 0.66 & $.971^{*}$ & 0.631 & $-.987^{*}$ & $.987^{*}$ & $.993^{* *}$ & 0.019 & $.998^{* *}$ & $.955^{*}$ & 1 & & & & \\
\hline Equitability & 0.901 & $.979^{*}$ & $.964^{*}$ & $.960^{*}$ & 0.944 & $.982^{*}$ & $.964^{*}$ & $.960^{*}$ & $.997^{* *}$ & $.986^{*}$ & $.997^{* *}$ & 0.45 & -0.157 & \begin{tabular}{|l|}
-0.759 \\
\end{tabular} & \begin{tabular}{|l|}
0.759 \\
\end{tabular} & 0.733 & \begin{tabular}{|l|}
0.774 \\
\end{tabular} & \begin{tabular}{|l|}
0.614 \\
\end{tabular} & 0.842 & 0.648 & 1 & & & \\
\hline Fisher_alpha & $.963^{*}$ & 0.932 & 0.946 & 0.948 & $.956^{*}$ & 0.927 & 0.945 & 0.948 & 0.843 & 0.789 & 0.886 & 0.817 & 0.312 & $-.976^{*}$ & $.976^{*}$ & $.967^{*}$ & 0.382 & 0.912 & $.997^{* *}$ & \begin{tabular}{|l|}
0.931 \\
\end{tabular} & 0.881 & 1 & & \\
\hline BergerParker & $-.965^{*}$ & \begin{tabular}{|l|}
-0.887 \\
\end{tabular} & -0.913 & -0.918 & -0.936 & \begin{tabular}{|l|}
-0.879 \\
\end{tabular} & \begin{tabular}{|l|}
-0.912 \\
\end{tabular} & -0.918 & \begin{tabular}{|l|}
-0.754 \\
\end{tabular} & -0.683 & -0.815 & -0.891 & -0.474 & $.991^{* *}$ & $-.991^{* *}$ & $-.988^{*}$ & -0.244 & $-.961^{*}$ & $-.981^{*}$ & $-.966^{*}$ & -0.796 & $-.978^{*}$ & 1 & \\
\hline Chao1 & 0.698 & 0.547 & 0.591 & 0.599 & 0.633 & 0.534 & 0.589 & 0.6 & \begin{tabular}{|l|}
0.363 \\
\end{tabular} & 0.277 & 0.442 & $.990^{* *}$ & 0.772 & -0.91 & 0.91 & 0.925 & -0.234 & $.966^{*}$ & 0.851 & $.963^{*}$ & 0.433 & 0.807 & \begin{tabular}{|l|}
-0.862 \\
\end{tabular} & 21 \\
\hline
\end{tabular}

* Correlation is significant at the 0.05 level (2-tailed).

** Correlation is significant at the 0.01 level (2-tailed).
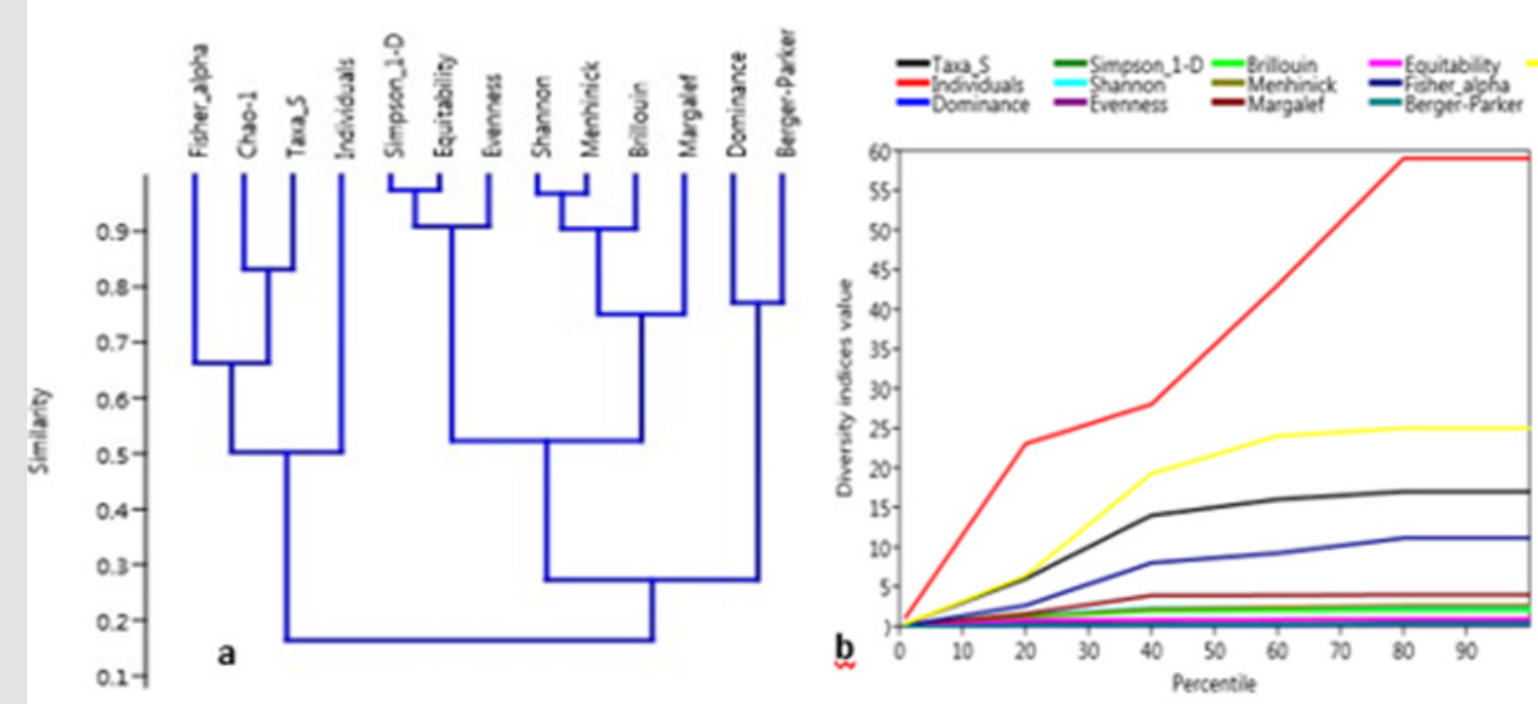

Figure 5: Bray-Curtis similarity dendrogram showing the grouping of diversity indices.

Furthermore, a model with interaction between TDS and sampling date was found to be significant $(\mathrm{p}<0.05)$ in predicting diversity (Diversity= TDS* sampling date). Thus, our study shows that the relationship between diversity and TDS will depend on the time of the year in which it is assessed(Abstract Figure 1). Although the diversity of macrobenthos didn't vary temporally, we record a temporal change in the relationship between diversity and TDS (and conductivity). Sampling date was found to have a synergistic effect on or an interaction with (Côte et al., 2016) the relationship between diversity indices and TDS. This suggests an indirect/ complex relationship between diversity and time; such that diversity may be predicted by temporal changes in these physicochemical parameters, in response to seasonal changes in salinity [14]. Our results suggest that DO and TDS (and conductivity), as water- 
chemistry parameters, are important for predicting the diversity of macrobenthic organisms in a spatially homogenous aquatic ecosystem such as the Lagos Lagoon.

\section{Conclusion}

This study provides insights on the impacts of environmental variables on the diversity of macrobenthic invertebrate communities of the Lagos Lagoon. The species composition and diversity were significantly influenced by environmental factors, thus the study revealed that the Lagos Lagoon is under anthropogenic pressure from organic and inorganic forms of pollutions.

\section{Acknowledgment}

The authors are grateful to the Nigerian Institute for Oceanography and Marine Research, Lagos, Nigeria for providing funds for the research and materials used during the study. We also wish to appreciate Dr. Yakub A. (HOD Biological oceanography), Clara Cassell and Dr. Sam Ivande for their support.

\section{References}

1. Madhushankha HM, Asanthi HB, Maithreepala RA (2014) The benthic macro-invertebrate diversity in relation to water quality of a stream habitat at Dediyagala, Sri Lanka. Sri Lanka J Aquat Sci 19: 15-29.

2. Lamptey E (2015) Eco-functional benthic biodiversity assemblage patterns in the Guinea Current Large Marine Ecosystem. Master's thesis, University of Ghana.

3. Morris EK, Caruso T, Buscot F, Fischer M, Hancock C, et al. (2014) Choosing and using diversity indices: insights for ecological applications from the German Biodiversity Exploratories. Ecology and Evolution $4(18): 3514-3524$.

4. Shah JA, Pandit AK (2013) Application of diversity indices to crustacean community of Wular Lake, Kashmir Himalaya. International Journal of Biodiversity and Conservation 5(6): 311-316.

5. Guerold F (2000) Influence of taxonomic determination level on several community indices. Water Res 34: 487-492.

6. Samidurai K, Saravanakumar A, Kathiresan K (2012) Spatial and tempora distribution of macrobenthos in different mangrove ecosystems of Tamil Nadu Coast, India. Enviro Moni Asses 184(7): 4079-4096.

7. Van Colen C, Verbelen D, Devos K, Agten L, Van Tomme J, et al. (2014) Sediment-benthos relationships as a tool to assist in conservation practices in a coastal lagoon subjected to sediment change. Biodiversity Conservation 23: 877-889.

8. Ajao EA (1996) Review of the state of the pollution of the Lagos lagoon Nigerian Institute of Oceanography and Marine Research (NIOMR) Technical Paper No. 106.

9. Obiefuna JN, Nwilo PC, Atagbaza AO, Okolie CJ (2012) Land Cover Dynamics Associated with the Spatial Changes in the Wetlands of Lagos/ Lekki Lagoon System of Lagos, Nigeria. Journal of Coastal Research 29(3): 671-679.
10. Swami BS, Suryawanshi UG, Karande A (2000) Water quality of Mumbai harbor-an update. Indian J Mar Sci 29: 111-115.

11. Ajao EA, Fagade SO (1990) A study of the sediments and communities in Lagos Lagoon, Nigeria. Oil and Chemical Pollution 7(2): 85-117.

12. Brown CA, Ajao EA (2004) Effects of topographical modification on the composition and abundance of macrofauna in southern Lagos Lagoon. West African Journal of Applied Ecology 5: 41.

13. Yakub AS, JK Igbo (2014) Assessment of benthic macroinvertebrate fauna of two contiguous coastal water bodies within barrier lagoon complex, western Nigeria. Journal of Environment and Human 1(2): 3946.

14. Nkwoji JA, Yakub A, Ajani GF, Balogun KJ, Renuer KO, et al. (2010) Seasonal variations in water chemistry and benthic macroinvertebrates of a South Western Lagoon, Lagos, Nigeria. J Amer Sci 6: 85-92.

15. Nkwoji JA, Edokpayi CA (2013) Hydrochemistry and community structure of benthic macroinvertebrates of Lagos Lagoon, Nigeria. Res. J Pharm Biol Chem Sci 4 (1): 1119-1131.

16. Ghasemi A, Zahediasl S (2012) Normality tests for statistical analysis: a guide for non-statisticians. International journal of endocrinology and metabolism 10(2): 486-489.

17. Yogendra K, Puttaiah ET (2008) Proceedings of the $12^{\text {th }}$ World Lake Conference pp. 342-346.

18. Ogunwenmo CA, K Kusemiju (2004) Annelids of a West African estuarine system. J. Environmental Biol 25(2): 227-237.

19. Deekay SN, JFN Abowei, C Chindah (2010a) Some physical and chemical parameters of Luubara creek, Ogoni land, Niger Delta, Nigeria. Research J. Environmental and Earth Sci 2(4): 199-207.

20. Deekay SN, JFN Abowei, JF Alfred Ockiya (2010b) Seasonal variation of some physical and chemical parameters of Luubara creek, Ogoni land, Niger Delta, Nigeria. Research J Environmental and Earth Sci 2(4): 208215 .

21. Victor R, O Onomivbori (1996) The effects of urban perturbation on the benthic macro invertebrates of a southern Nigeria stream. In: F Schiomer Biland, (Eds). SPB Academic Publishing Amsterdam, The Netherlands pp: 223-238.

22. Edokpayi CA, EC Osimen (2001) Hydrobiological studies on Ibiekuma River at Ekpoma, Southern Nigeria after Impoundment: The faunal characteristics. Afr J Sci Tech pp: 72-81.

23. Johnson KS, Sakamoto CM, Coletti LJ (2009) An improved algorithm for the computation of nitrate concentrations in seawater using an in situ ultraviolet spectrophotometer methods. Limnol. Oceanogra 7: 132-140.

24. Uwadiae RE (2009) Response of Benthic Macroinvertebrates to Salinity Gradient in a Sandwiched Coastal Lagoon. Report and Opinion 1(4): 4555.

25. Dash MC (2003) Fundamental of Ecology. (2 ${ }^{\text {nd }}$ Edn.). Tata McGrawHill publishing company limited, New Delhi, India.

26. Ravera 0 (2001) A comparison between diversity, similarity and biotic indices applied to the macroinvertebrate community of a small stream: The Ravella river (Como Province, Northern Italy). Aquatic Ecol 35: 97107 
ISSN: 2574-1241

DOI: $10.26717 /$ BJSTR.2020.30.004885

Bassey BO. Biomed J Sci \& Tech Res

(C) This work is licensed under Creative

Submission Link: https://biomedres.us/submit-manuscript.php

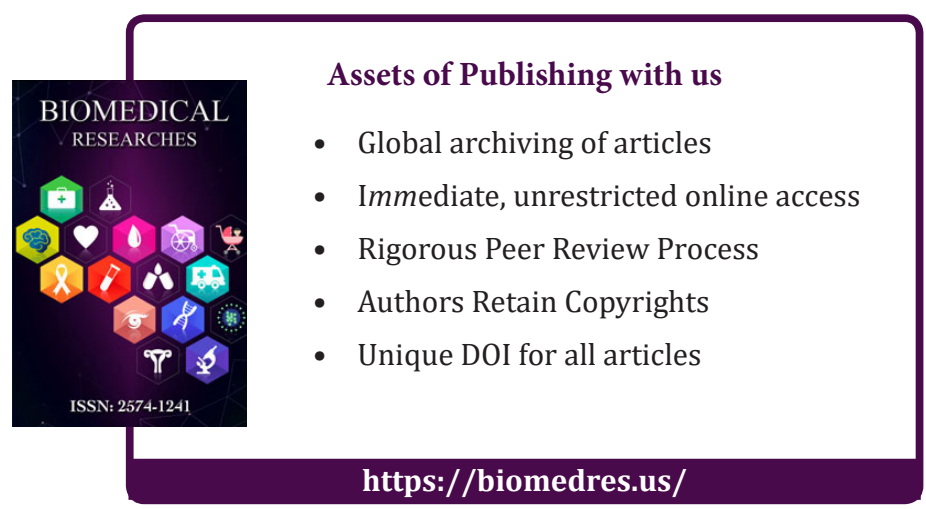

